\title{
Nekoliko misli o profilu nastavnika kao odgojitelja
}

\author{
Aleksandra GOLUbOVIĆ* \\ - Petra domá́inović** \\ • https://doi.org/10.31823/d.27.4.8 • \\ UDK: 1:37.01 • Pregledni članak \\ Primljeno: 29. siječnja 2019. • Prihvaćeno: 2. prosinca 2019.
}

${ }^{*}$ izv. prof. dr. sc.

Aleksandra Golubović,

Filozofski fakultet

Sveučilišta u Rijeci,

Sveučilišna avenija 4, 51000 Rijeka, agolub@ffri.hr

** Petra Domaćinović,

Filozofski fakultet

Sveučilišta u Rijeci,

Sveučilišna avenija 4,

51000 Rijeka,

domacinovicp@gmail.com

Sažetak: U ovom radu želimo prikazati nove trendove i mogućnosti u sagledavanju uloge nastavnika kao odgojitelja primjerenoga našemu dobu. Kada kažemo odgojitelj mislimo na profesionalca, tj. stručnjaka koji je na svim razinama odgojnoobrazovnoga sustava zadužen za senzibiliziranje i primjenu relevantnih odgojnih teorija i praksi. Nastavnici tijekom cijeloga svojega radnoga vijeka trebaju ići ukorak s napretkom stručnoga područja koje poučavaju, kao i sa spoznajama vezanima uz odgoj i obrazovanje, ponajviše iz područja pedagogije, psihologije, didaktike i filozofije odgoja. Zato nastavnika, koji je ujedno i odgojitelj, stavljamo u središte naših razmišljanja $i$ istraživanja. Imperativ odgojiteljskoga posla jest stalan profesionalni razvoj. Zato nudimo profil koji obuhvaća zahtjeve za nastavnikom odgojiteljem 21. stoljeća, što znači da prati razvoj ključnih kompetencija važnih za odgojni rad u suvremenoj školi, a temelji se na usvajanju novih znanja, vještina $i$ sposobnosti te usavršavanju ranije stečenih kompetencija. Jer uz nastavnika koji je dobar odgojitelj i škole će moći uspješnije ispunjavati svoje odgojne zadaće.

Ključne riječi: nastavnik odgojitelj, odgoj, obrazovanje, kompetencije, refleksivni praktičar, odgojitelj emancipator.

\section{Uvod}

Uvodno želimo naglasiti da se pod odgojiteljem u ovom radu ne misli samo na odgojitelje u vrtiću, na koje se prvobitno naziv i odnosi, već na odgojitelje koji se pojavljuju u cjelokupnom odgojno-obrazovnom sustavu, dakle na sve 
nastavnike koji utječu na odgoj djeteta od njegove rane dobi do fakultetskih dana. Ovdje, drugim riječima, ponajviše govorimo o nastavniku kao odgojitelju u školi čija se uloga pokazuje iznimno važnom za život svake osobe, a osobito adolescenata. Nudimo dakle profil nastavnika uz kojeg je nezaobilazno vezana uloga odgojitelja. Izrada samoga profila inspirirana je raspravama utemeljenim na iščitavanju brojne filozofske i pedagoške literature relevantne za odgoj budućih naraštaja. Zato smo u raspravu odlučile uključiti filozofiju odgoja, jer temelj odgoja vidimo upravo u vrlinama koje nastavnik treba posjedovati i prenositi na učenike, a koje je kao glavne u svom etičkom nacrtu davno prepoznao i Aristotel. Uvođenje filozofije odgoja u raspravu o odgoju i obrazovanju pretpostavlja viđenje odgoja kroz izgradnju i usavršavanje učenikove intelektualne te osobito etičke dimenzije. ${ }^{1}$ Važnost promišljanja o profilu nastavnika koji odgaja svoje učenike na njihovu dobrobit, ali i na dobrobit društva u kojem žive, vidimo u nekoliko ključnih elemenata. Kvaliteta je prvi od njih. Kvalitetna škola naime ima kvalitetne nastavnike - koji su nadalje sposobni poticati učenike na kvalitetan rad i razvitak, tj. vlastito ponajbolje ostvarenje. ${ }^{2} \mathrm{Tu}$ u prvom redu mislimo na pomicanje granica u odgojnim nastojanjima, a da bi nastavnik uopće bio u mogućnosti odgojno utjecati prvo što treba učiniti jest kritički preispitati tradicionalni, autoritarni pristup, kojega se čak i danas mnoge škole još uvijek drže (iako su smjernice za napuštanje takvoga načina rada svjetlo dana ugledale još u prošlom stoljeću). Time mislimo na stilove rukovođenja razredom. Možemo razlikovati autoritarni i autoritativni stil, pri čemu je prvi usmjeren na naredbe, poslušnost autoritetu, kazne ili nagrade te konformizam, dok je drugi, koji smatramo odgojno poželjnijim i efikasnijim, usmjeren na razvijanje samostalnosti, odgovornosti, iskustvenoga učenja te poticanje i razvoj kritičkoga mišljenja, upravo u skladu s odgojem za vrline.

Profil nastavnika odgojitelja koji nudimo uvažava sve važne sastavnice suvremenoga odgoja, a podrazumijeva i stalno traganje za novim, boljim i kvalitetnijim pristupima odgoju. To ne znači da ne uzimamo u obzir i tradicionalne pristupe, što je vidljivo iz odabira literature i filozofa koji su se bavili odgojem. Pod tradicionalnim pristupom podrazumijevamo primjenu smjernica koje proizlaze iz stare didaktičke škole, pedagoškoga pravca koji s djelovanjem započinje u 17. stoljeću, a u čije okrilje možemo svrstati i Jean-Jacquesa Rousseaua, dok kritiku toga pristupa donosi nova škola, pravac koji se javlja početkom 19. stoljeća i koji okuplja velikane odgoja poput Marije Montessori i Johna Deweyja. ${ }^{3}$ Ono što smo prepoznali kao ključnu razliku tradicionalnoga i suvremenoga odgoja jesu ciljevi odgojno-obrazovnoga procesa. Zagovaramo onaj pristup koji prati potrebe učenikova razvoja, odnosno

\footnotetext{
${ }^{1}$ Usp. J. MARINKOVIĆ, Metodika nastave filozofije, Zagreb, 2008.

${ }^{2}$ Usp. W. GLASSER, Nastavnik u kvalitetnoj školi, Zagreb, 1999., 18.

${ }^{3}$ Usp. I. LAVRNJA, Poglavlja iz didaktike, Rijeka, 1998.
} 
čiji je fokus na razvitku vrlina, a ne samo na usvajanju što veće količine znanja. Nastavnik koji može ostvariti takav pristup i sam mora razvijati vrline ${ }^{4}$ koje će poticati kod učenika. Posjedovanje vrlina ${ }^{5}$ postalo je u naše vrijeme problematično, osobito zbog pronalaska niza načina da se taj ideal zaobiđe. ${ }^{6}$ Naime nastavnik je odgovoran kreator, a ne samo izvoditelj nastavnoga procesa ${ }^{7}$, što znači da treba čvrsto stajati iza odgojne poruke koju želi prenijeti.

Drugi razlog zbog kojega nudimo profil nastavnika čija je glavna zadaća odgajati jest poticajne naravi. Baviti se odgojem bez propitivanja ključnoga čimbenika: odgoja, kao i nastavničke uloge odgojitelja, sigurno je nemoguće. Pod poticajem mislimo na potrebu da se svi, dakle i iskusni i neiskusni nastavnici, profesionalci, ali i mladi nastavnici koji tek stupaju u kontakt s odgojnim radom, kontinuirano osvještavaju i preispituju vlastiti rad, koji će im biti učinkovitiji i uspješniji ako dodatno porade na svojim kompetencijama i umijećima koja bi trebala biti u skladu s odgojem budućnosti. ${ }^{8}$ Treći razlog zbog kojega govorimo o profilu nastavnika odgojitelja upravo je činjenica da je ovdje fokus na samom odgojitelju, osobi koja se trudi postići idealno u često ne baš idealnim uvjetima: »nastavnički posao bi trebao biti najprofesionalniji od svih, no to je posao u kojem se ljude koji ga obavljaju u tome onemogućuje. $\ll^{9}$ Zato u ovom radu pružamo smjernice koje bi trebale pomoći nastavnicima - čija je važna zadaća upravo odgajanje - da se ponajprije usredotoče na ono što im omogućava kvalitetno obavljanje te zadaće, a manje na čimbenike koji to onemogućavaju. Također o profilu nastavnika u čijem je interesu da bude vrstan odgojitelj govorimo i zbog potrebe odmaka od tradicionalnosti, ne zato što je tradicija postavila loše temelje, već zato što škola budućnosti mora neprestano propitivati didaktičke elemente te mijenjati svoje temelje u skladu s promjenama u društvu. Pedagoška praksa niz godina radi na tome da se prijeđe na novi, osuvre-

\footnotetext{
${ }_{4} \gg$ Vrline su kao karakterno-kontekstualne dispozicije čovjekovom karakteru nešto vrlo prisno, te se iz te činjenice promatraju kao objektivno-činjenična danost prema čemu bi on trebao težiti u ispunjenju svojeg ergona tj. vlastite svrhe te, što je također važno, $u$ isto vrijeme bivaju uvjet ispunjena sretna i zadovoljna života uopće. $\ll$ S. RADIĆ, Dva različita pristupa u rearistotelizaciji suvremene etike. Neoaristotelizam Alasdaira MacIntyrea i Marthe Nussbaum, u: Filozofska istraživanja 33(2013.)4, 648.

${ }^{5}$ Usp. Virtue Ethics, u: Standford Encyclopedia of Philosophy, dostupno na: https://plato.stanford. edu/entries/ethics-virtue/ (26. 4. 2019.)

${ }^{6} \gg$ Vrline su postale puke vrijednosti koje su se mogle zamijeniti. To je nagovijestio i Nietzsche, filozof koji se usudio pokazati kako se moral otrcao i izgubio smisao. Ž. SENKOVIĆ, Praxis »nakon vrline «. Različita čitanja Aristotela: Alasdair MacIntyre i Hannah Arendt, u: Filozofska istraživanja 33(2013.)4, 638.

${ }^{7}$ Usp. J. MARINKOVIĆ, Metodika nastave filozofije, Zagreb, 2008., 14.

${ }^{8}$ Usp. E. MORIN, Odgoj za budućnost, Zagreb, 2002.

${ }^{9}$ W. GLASSER, Nastavnik u kvalitetnoj školi, Zagreb, 1999., 28.
} 
menjeni, kvalitetniji odgojno-obrazovni sustav. Jedan od gorućih problema u tom kontekstu jest kako učenika postaviti u suvremeni položaj ako nemamo suvremeno osposobljene nastavnike odgojitelje. ${ }^{10}$

Zato odmah na početku nudimo listu kvaliteta (vrlina) ${ }^{11}$ koje smatramo važnima da ih nastavnik kao odgojitelj posjeduje te da ih zna uspješno prenositi na svoje učenike jer je ključno da odgojem oblikuje one crte osobnosti kod učenika na temelju kojih će oni prosuđivati i djelovati u skladu s vrijednostima: »jednom kada je učenik odgojen spreman je da kao samostalno i zrelo biće preuzme svoju ulogu u društvu. $\ll{ }^{12}$ Vrline ${ }^{13}$ koje je kao temelj ljudskoga karaktera još u antici postavio u središte zanimanja Aristotel, ${ }^{14}$ a koje i današnji nastavnik odgojitelj treba posjedovati i pomoću njih odgajati jesu: autonomija ${ }^{15}$, slobodoumnost, temeljitost, odgovornost, moralna zrelost, empatičnost i samopouzdanost. Sve te vrline trebaju biti usklađene s kompetencijama potrebnim za obavljanje nastavničkoga posla u okviru odgojno-obrazovnoga sustava, kao i s potrebnim umijećima kako bi se poučavanje provodilo na primjeren način.

Naglašeno je na početku kako je fokus ovoga rada na nastavniku kao odgojitelju, ali kratko ćemo se osvrnuti i na odgojenike jer sve navedene vrline, umijeća i kompetencije koje nastavnik koji odgaja treba posjedovati služe upravo tomu da bi pružili kvalitetan odgoj njima - učenicima: »učenik je istodobno i svrha i cilj nastavnog procesa. Učenik je, bez sumnje, glavna i vrhunska vrijednost nastavnog procesa i odgoja uopće. $\ll{ }^{16}$ Prema svemu do sad napisanom možemo utvrditi kako je cilj

${ }^{10}$ Usp. P. SKOK, Učenik u suvremenoj nastavi: jučer, danas, sutra, Lučko, 1997., 31.

${ }^{11} \gg$ Vrlina je izvrsna osobina karaktera. To je dispozicija, dobro ukorijenjena u onome koji ju posjeduje - nešto što, kako kažemo, ide skroz do kraja, za razliku od navike kao što je piti čaj - primijetiti, očekivati, cijeniti, osjetiti, poželjeti, izabrati, djelovati, i reagirati na određene karakteristične načine. Posjedovati vrlinu znači biti određena osoba s određenim složenim načinom razmišljanja.« Virtue Ethics, u: Standford Encyclopedia of Philosophy, dostupno na: https://plato.stanford.edu/ entries/ethics-virtue/ (26. 4. 2019.)

${ }^{12}$ A. GOLUBOVIĆ, L. ANGELOVSKI, Metodika nastave filozofije, Rijeka, 2017., 26.

13 »Koncept vrline je pojam nečega što čini osobu koja ju posjeduje dobrom: kreposna osoba je moralno dobra, izvrsna ili divna osoba koja djeluje i osjeća kako treba.« Usp. Virthue Ethics, u: Standford Encyclopedia of Philosophy, dostupno na: https://plato.stanford.edu/entries/ethics-virtue/ (26. 4. 2019.)

${ }^{14} \mathrm{U}$ pokušaju rješavanja suvremenih etičkih problema primjenjuju se temeljne postavke aristotelovske etike, što autori nazivaju rearistotelizacijom, pri čemu se ona očituje u svojem najpoznatijem tematskom bloku, a to je upravo suvremena etika vrlina. Usp. S. RADIĆ, Dva različita pristupa u rearistotelizaciji suvremene etike, 646 .

15 »Autonomna djeca posjeduju iznadprosječnu odgovornost i to je ono najposebnije kod njih.« J. JUUL, Četiri vrijednosti koje će djecu pratiti do kraja života, Split, 2018., 58.

${ }^{16}$ Isto, 11. 
ovoga rada pokazati da s obzirom na promjene koje su se dogodile i događaju se u odgojno-obrazovnom sustavu učenik uvijek treba biti u središtu, jer je on glavni akter svakoga nastavnoga procesa. Dosadašnja praksa pokazuje kako je temeljno obilježje školskoga sustava favoriziranje obrazovnih, a ne odgojnih ciljeva, pri čemu treba istaknuti da su obrazovni ciljevi neodvojivi od odgojnih, što znači da tek zajedno omogućuju ostvarivanje uspješne nastave. ${ }^{17}$ Zato unutar ovoga rada nudimo potpunije i djelotvornije smjernice kako bi se više afirmirala odgojna uloga škole: »Odgojna funkcija škole traži da svaki nastavnik u nastavi svog predmeta i u svim ostalim oblicima školskog rada, kao odgajatelj novih naraštaja, cijeni odgojne zadatke i da ih, u suradnji s učeničkim razrednim zajednicama, ostvaruje. ${ }^{18}$

\section{Koje vrline nastavnika odgojitelja trebamo za novo doba?}

Zadaća odgajanja jedna je od najvažnijih, najodgovornijih, a možda i najtežih zadaća s kojom se svakodnevno susreće svaki nastavnik. I ona se ne odvija bez problema i poteškoća. Onaj koji odgaja trebao bi, među ostalim, uvijek imati na umu da su samostalnost i sloboda u donošenju odluka (dakle moć dobre procjene ili prosudbe $)^{19}$ među najvažnijim aspektima odgoja. Smatramo da su samostalnost i sloboda elementi koji krucijalno obilježavaju specifičnu fazu odrastanja, tj. prijelaz iz djeteta u odraslu, zrelu osobu. Ali i cjelokupan život svake osobe. Riječ je, zapravo, o preduvjetima odgoja, bilo roditeljskoga ${ }^{20}$ bilo nastavničkoga. Uz to je iznimno važna i odgovornost ${ }^{21}$ pri donošenju odluka jer govorimo o odgoju učenika koji trebaju postati odgovorni subjekti, u prvom redu, za donošenje vlastitih pravilnih, moralnih odluka na temelju kojih će dalje moći pravilno djelovati i ponašati se. Ono što želimo posebno istaknuti jest da se i odgovornost i odgoj služe istim glagolom, a to je izgraditi. Odgojem izgrađujemo osobu za odgovorno donošenje odluka - a postupci za koje se donose te odluke također doprinose njezinoj izgradnji. ${ }^{22} \mathrm{Na}$ stavni proces stoga je uvelike obilježen odgojem. Drugim riječima, nastavnici rade iznimno ozbiljan i odgovoran posao jer: »čovjekova budućnost je u velikoj mjeri ovisna o njegovoj izgrađenosti i moralnoj zrelosti. $\ll^{23}$ Škola je mjesto gdje se učenici pripremaju za život u svijetu odraslih, stoga je dobro upozoriti ih da u svemu

\footnotetext{
${ }^{17}$ Usp. A. GOLUBOVIĆ, L. ANGELOVSKI, Metodika nastave filozofije, Rijeka, 2017.

${ }^{18}$ A. VUKASOVIĆ, Prinosi unaprjeđivanju odgojnog rada, Zagreb, 1979., 1.

19 »Aristotelova teorija vrline visoko ističe važnost prosudbe prilikom izbora sredstava za postizanje odgovarajućih svrha, činjenje prave stvari na pravom mjestu, u pravo vrijeme, na pravi način.« Ž SENKOVIĆ, Praxis $\gg$ nakon vrline $\ll, 634$.

${ }^{20}$ Usp. J. JUUL, Četiri vrijednosti koje će djecu pratiti do kraja života, Split, 2018.

${ }^{21}$ Usp. F. SAVATER, Etika za Amadora, Zagreb, 1998., 30-33.

${ }^{22}$ Usp. J. DEWEY, Vaspitanje i demokratija (uvod u filosofiju vaspitanja), Cetinje, 1966., 73-164.

${ }^{23}$ A. VUKASOVIĆ, Prinosi unaprjedivanju odgojnog rada, Zagreb, 1979., 9.
} 
što čine budu temeljiti i odgovorni ${ }^{24}$, da se znaju staviti na mjesto druge osobe ${ }^{25}$, da budu empatični i ne krše temeljna ljudska prava. ${ }^{26} \mathrm{Uz}$ to ih treba odgajati da budu zreli i puni samopouzdanja ${ }^{27}$, osobito kada se suočavaju s izazovima u životu. Važno je i da posjeduju samopoštovanje i budu proaktivni. ${ }^{28}$ Nastavnika čija je ključna zadaća odgojno utjecati i pripomoći u razvoju djetetove osobnosti, tj. nastavnika koji uistinu » uzgaja « djetetove vrline imao je na umu i sam Rousseau ${ }^{29}$, čiji je temeljni zahtjev i načelo povratak prirodi, odnosno neometano, prirodno razvijanje djetetovih sposobnosti. Kod Rousseaua je riječ upravo o tome da se odgoj i obrazovanje ne bi trebali temeljiti na stjecanju znanja, nego na razvijanju vrlina ${ }^{30}$, o čemu su govorili i njegovi prethodnici Platon i Aristotel. ${ }^{31} \mathrm{U}$ suvremenoj filozofiji, $\mathrm{u}$ kojoj etika vrlina ${ }^{32}$ predstavlja jedan od triju glavnih pristupa unutar normativne etike ${ }^{33}$, fokus je ponovno na vrlinama koje rezultiraju dobrim i sretnim životom. ${ }^{34}$ Slično tvrdi i poznata suvremena filozofkinja Hannah Arendt ${ }^{35}$, po kojoj su vrline upravo rezultat odgoja ili poučavanja. ${ }^{36}$ Upravo zato valja naglasiti da nastavnik - odgojitelj

${ }^{24} \gg$ Dijete u odgojnoj situaciji mora shvatiti ideje odgoja kao vlastite, i trebalo bi razumjeti njihovu primjenu ovdje i sada, u okolnostima njegova stvarnog života. Od samog početka njegovog odgoja, dijete treba iskusiti radost otkrića.« A. N. WHITEHEAD, The Aims of Education, u: W. FRANKENA, Philosophy of Education, Canada, 1965., 2.

25 »Poistovjećujući se s drugima, djeca se uče empatiji. U tom smislu igra je važan dio razvoja društvenih vještina i širenja vidika.« I. DISSING SANDAHL, Igra na danski način, Zagreb, 2019., 32.

${ }^{26}$ Usp. F. SAVATER, Etika za Amadora, Zagreb, 1998., 113-135.

${ }^{27} \gg U$ odgoju i obrazovanju važno se usredotočiti na razvoj samopouzdanja jer u djece potiče razvoj otpornosti koja je dokazano jedan od ključnih čimbenika uspjeha u odrasloj dobi, i to ne samo profesionalnog i privatnog uspjeha, nego uspješne, sretne i cjelovite osobe.«I. DISSING SANDAHL, Igra na danski način, 28.

${ }^{28}$ Izgraditi zdravo samopoštovanje učiteljima bi trebao biti jedan od glavnih ciljeva. Usp. J. JUUL, Agresivnost! Nov i opasan tabu? Vodič za bolje razumijevanje agresivne djece i mladih, Split, 2018., 149.

${ }^{29}$ Usp. J. J. ROUSSEAU, Emil ili o odgoju, Beograd, 1989.

${ }^{30}$ Usp. Virtue Ethics, u: Standford Encyclopedia of Philosophy, dostupno na: https://plato.stanford. edu/entries/ethics-virtue/ (26. 4. 2019.)

${ }^{31}$ Usp. PLATON, Država, Zagreb, 1997.; ARISTOTEL, Nikomahova etika, Zagreb, 1982.

${ }^{32}$ Etika vrlina definira moralni status djelovanja krjeposne osobe i moralno ispravnih radnji koje bi krjeposna osoba trebala odabrati i učiniti. Usp. V. STRAHOVNIK, Identity, Character and Ethics. Moral Identity and Reasons for Action, u: Synthesis Philosophica 51(2011.)1, 67-77., 72.

${ }^{33}$ Usp. Virtue Ethics, u: Standford Encyclopedia of Philosophy, dostupno na: https://plato.stanford. edu/entries/ethics-virtue/, (26. 4.2019.)

${ }^{34}$ Usp. V. STRAHOVNIK, Globalization, Globalized Ethics and Moral theory, u: Synthesis Philosophica 48(2009.)2, 209-218.

${ }^{35}$ Uz MacIntyrea, Voegelina, Straussa i Arendt pripada filozofima koji su pokušali protumačiti suvremeno doba novim čitanjem antičkih autora. Usp. Ž. SENKOVIĆ, Praxis »nakon vrline «, 632.

${ }^{36}$ Usp. H. ARENDT, O zlu: predavanje o nekim pitanjima moralne filozofije, Zagreb, 2006., 37. 
novoga doba, najprije sam treba posjedovati vrline da bi ih kasnije mogao prenositi na mlade naraštaje. ${ }^{37}$

Mnogo je odgojnih aspekata koje osoba koja odgaja mora imati u vidu pri svakom odgojnom nastojanju, a koji bi trebali biti obuhvaćeni temeljnim zakonom odgojnoga rada - zakonom skladnoga jedinstvenoga djelovanja. ${ }^{38} \mathrm{Od}$ toga polaze nastavnici i obrazovni sustav od samih pedagoških početaka i takav odgojni rad iziskuje se i danas jer osigurava razvoj djeteta na svim razinama: intelektualnoj, tjelesnoj, emocionalnoj, duhovnoj, socijalnoj i moralnoj. ${ }^{39}$ Pri tome u suvremeno doba najveći naglasak treba staviti upravo na moralnu komponentu ${ }^{40} \mathrm{iz}$ razloga što se pod biti odgojen u prvom redu smatra biti intelektualno i moralno usavršena ili izgrađena osoba ${ }^{41}$, a razvoj moralne komponente uvelike je ovisan i o društvenom okviru u kojem se odgaja, ${ }^{42} \mathrm{~s}$ obzirom na to da odgoj podilazi tradicijama, običajima, oblicima ponašanja. ${ }^{43}$ Kada se govori o moralu, ne može se ne povezati značenje moralnoga odgoja ${ }^{44}$ za formiranje karaktera i identiteta, ${ }^{45}$ pri čemu nije samo na nastavniku da odgaja učenika moralnim postupcima već i da učenici nauče odabrati kakvom osobom žele postati. ${ }^{46}$

Stoga ćemo nešto više reći o profesionalnoj kompetenciji nastavnika odgojitelja i što pod time podrazumijeva uvriježena pedagoška praksa, a pokazuje se osobito

${ }^{37}$ Usp. Ž. SENKOVIĆ, Praxis »nakon vrline $\ll, 634$.

$38 \gg$ Ako želimo ostvariti pozitivne rezultate u odgojnom radu, moramo nastojati da svi odgojni čimbenici, u najvećoj mogućoj mjeri, djeluju skladno i u istom pravcu. « A. VUKASOVIĆ, Prinosi unaprijedivanju odgojnog rada, Zagreb, 1979., 8.

${ }^{39}$ Danas se sve više ističe potreba moralnoga odgoja. Usp. A. GOLUBOVIĆ, Aktualnost Rousseauovih promišljanja filozofije odgoja s posebnim osvrtom na moralni odgoj, u: Acta Iadertina 10(2013.)1, 25-36.

${ }^{40}$ U suvremenoj literaturi koja se bavi odgojem naglasak pri moralnom odgoju stavljen je i na igru: »Igra djecu uči društvenim i moralnim normama i vrijednostima, odnosno što je ispravno, a što pogrešno u odnosu prema drugima.« I. DISSING SANDAHL, Igra na danski način, 32.

${ }^{41}$ Usp. A. GOLUBOVIĆ, Odgojne implikacije Kierkegaardove antropologije. Od antropologije do filozofije odgoja u misli Sorena Kierkegaarda, u: Diacovensia 23(2015.)2, 213-228., 215.

${ }^{42}$ Usp. S. RADIĆ, Dva različita pristupa u rearistotelizaciji suvremene etike, 646.

${ }^{43} \gg$ Jastvo mora pronaći svoj moralni identitet kroz svoju pripadnost zajednicama kao što su zajednice obitelji, susjedstva, grada i plemena.« Isto, 648 .

${ }^{44} \gg$ Slijedeći Platona i Aristotela, moderna etika vrlina uvijek je naglašavala važnost moralnog odgoja, ne kao usađivanja pravila nego kao osposobljavanja karaktera.« Usp. Virtue Ethics, u: Standford Encyclopedia of Philosophy, dostupno na: https://plato.stanford.edu/entries/ethicsvirtue/\#FutuDire (26. 4. 2019.)

${ }^{45}$ Usp. V. STRAHOVNIK, Identity, Character and Ethics, 67-77.

${ }^{46}$ Usp. isto, 67-77. 
važnim za nastavnike koji nastoje promicati odgojne vrijednosti koje doprinose razvijanju poželjnih vrlina, a time i formiranju moralno ispravnih karaktera. Govoreći o profesionalnoj kompetenciji nastavnika, koji je ujedno i odgojitelj, misli se u prvom redu na njegov utjecaj na prepoznavanje i iskorištavanje svih djetetovih potencijala te razvijanje njegovih individualnih karakteristika jer, naravno, opće je poznato da odgojitelj može poticati ili, u nesretnijoj inačici, ograničavati razvoj djeteta svojom prikladnom ili neprikladnom praksom. Prema rječniku, kompetencija je priznata stručnost, sposobnost kojom tko raspolaže ${ }^{47}$ Pri tome unutar pedagoške literature postoji i pedagoška kompetencija. ${ }^{48}$ Zato ćemo sada govoriti o profesionalnoj kompetenciji koja je potrebna svakom nastavniku odgojitelju za kvalitetno obavljanje posla. Ono što je napisao kanadski odgojitelj Michael Fullan, a prenosi nam Mirjana Šagud u svojoj knjizi Odgajatelj kao refleksivni praktičar jest: »u postmodernom društvu svaki je pojedinac odgovoran za promjene, a u tome odgajatelji imaju jednu od važnijih uloga budući da pripremaju najmlađe članove društva da u tim promjenama sudjeluju. $\ll{ }^{49}$ Dakle odgojitelj, ako je profesionalan u svom poslu, treba biti svjestan svoje odgovornosti pri donošenju svake odluke. $U$ prilog rečenomu o profesionalnosti i važnosti nastavničke odgojiteljske uloge ide i teza kojom se tvrdi da umjetnost i znanost o odgoju zahtijevaju genijalnost i vlastitu studiju te da su ta genijalnost i ta znanost mnogo više

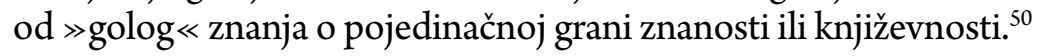

$S$ naglaskom na veću stručnost dogodile su se i promjene unutar obrazovanja nastavnika te formiranja njihove odgojiteljske uloge pa se navodi i kako se od $\gg$ odgajatelja - posrednika znanja, traže odgajatelji - aktivni graditelji znanja u zajednici koja se razvija i uči. $\ll{ }^{51}$ Pitanje na koje sada treba odgovoriti jest što je to potrebno kompetentnom, profesionalnom nastavniku odgojitelju da bi postao aktivni graditelj znanja. Na to pitanje dano je mnogo odgovora autora iz područja pedagogije, od kojih većinu nudi i autorica Šagud, na koju se ovdje pozivamo, ali ono što nas najviše zanima jest popis kvaliteta koje odgojitelj prema njezinu mišljenju treba imati. Prema tomu popisu odgojitelj jest:

1. osoba koja kontinuirano uči i želi pronalaziti i provjeravati različite modele bez pretenzije da unaprijed ima odgovor na sva pitanja, želi istražiti ono što ne zna; 2. osoba s izraženom potrebom napredovanja u osobnom i profesionalnom smislu; 3.

\footnotetext{
${ }^{47}$ Usp. V. ANIĆ, Veliki rječnik hrvatskoga jezika, Zagreb, 2006., 596.

48 »Profesionalna mjerodavnost visoke stručne razine, u smislu kvalitetne pedagoške izobraženosti i osposobljenosti učiteljstva.« A. MIJATOVIĆ, Leksikon temeljnih pedagoških pojmova, Zagreb, 2000., 158.

${ }^{49}$ M. FULLAN, Change forces, u: M. ŠAGUD, Odgajatelj kao refleksivni praktičar, Petrinja, 2006., 8.

${ }^{50}$ Usp. A. N. WHITEHEAD, The Aims of Education, 4.

${ }^{51}$ M. ŠAGUD, Odgajatelj kao refleksivni praktičar, 8.
} 
dobar promatrač i slušatelj djece; 4. poznavatelj sredine u kojoj radi sa svim socijalnim, kulturnim i ekonomskim različitostima; 5. poznavatelj zakonitosti djetetova rasta i razvoja uz prihvaćanje individualnih različitosti i kvaliteta; 6. poznavatelj procesa učenja predškolskoga djeteta - različitih načina i intenziteta; 7. sklon postavljanju pitanja o motivima djece - zaključak ostavlja otvoren, ne žuri, istražuje, uzima u obzir mišljenje drugih, otvoren za riskantne ideje, za postavljanje pitanja, za istraživanja; 8. sposoban preuzeti rizik i ne opterećivati se unaprijed postavljenim planom; 9. spreman za kompromis, omogućuje improvizacije i kreativno izražavanje; 10. fleksibilan - sredinu organizira prema konkretnim potrebama i kontekst doživljava nepredvidljivim. ${ }^{52}$

Mislimo da je tim popisom dan dobar uvid u glavne kompetencije nastavnika jer je nastao na temelju suradnje i proučavanja stručnjaka različitih profila koji se u većini odrednica slažu. Popis je prvobitno nastao kao rezultat proučavanja kvalitetnoga obrazovanja odgojitelja djece vrtićke dobi te nižih razreda osnovne škole, što ne znači da nije primjenjiv i na odgojitelje koji svoj odgojni rad obavljaju u kasnijim fazama obrazovanja. ${ }^{53}$ Da pojasnimo: nastavnik na svim obrazovnim razinama i neovisno o predmetu poučavanja trebao bi stalno istraživati i učiti, trebao bi se kontinuirano profesionalno usavršavati i pratiti nova saznanja i promjene u svijetu znanosti i tehnike, trebao bi znati uspostaviti dobar odnos s učenicima koji je temeljno usmjeren na aktivno promatranje i slušanje. Da bi taj odnos bio kvalitetan, nastavnik bi trebao poznavati svoj razred i učenike te njihove različitosti, trebao bi znati glavne teorije vezane uz djetetov razvoj koje svaki nastavnik u određenoj fazi studiranja i upoznaje i uči. Trebao bi biti upoznat s procesima učenja svojih učenika kako bi u skladu s time mogao kreirati svoj pristup i načine rada u konkretnoj nastavnoj situaciji, trebao bi istraživati različite mogućnosti, preuzimati rizik i odgovornosti, biti spreman na svaku oluju i omogućavati improvizacije te se znati snalaziti u danom trenutku, dakle u nepredvidljivim nastavnim situacijama biti što je moguće više fleksibilan, i sve to činiti na dobrobit svojih učenika. Sve navedene kvalitete zapravo su i potvrđene i razložene u pojedinim dijelovima rada. ${ }^{54}$ Ali u fokusu ovoga rada nisu sve navedene kvalitete nastavnika, već samo one koje razvija nastavnik čija je ključna zadaća odgajanje, a ne poučavanje. Sukladno vrlinama (kvalitetama) koje smo naveli na početku rada smatramo da taj popis, nastao u suradnji brojnih autora, potkrjepljuje našu tvrdnju da nastavnik uz temeljne profesionalne kompetencije treba imati kvalitete kojima doprinosi promicanju isključivo

\footnotetext{
${ }^{52}$ Isto, 10.

${ }^{53}$ Usp. isto.

${ }^{54}$ Usp. J. MARITAIN, Man's Nature and the Aims of His Education, u: W. FRANKENA, Philosophy of Education, Canada, 1965., 38-39.; R. PETERS, Must an Educator Have an Aim, u: W. FRANKENA, Philosophy of Education, Canada, 1965., 48-49.; J. MARITAIN, Intellectual and Moral Education, u: W. FRANKENA, Philosophy of Education, Canada, 1965., 87-88.
} 
odgojnih vrijednosti. Konkretno, iz ranije ponuđenoga popisa smatramo da treba izdvojiti kompetenciju izgrađivanja kvalitetnoga odnosa s učenicima, odnosno kvalitetnu komunikaciju čije su glavne karakteristike sloboda i ravnopravnost u izražavanju mišljenja, komunikacija koja se odvija bez prijetnji i omalovažavanja, drugim riječima, temeljna otvorenost za komunikaciju, iskrenost, jasnoća, usredotočenost na učenike tijekom komunikacije te socijalna reverzibilnost pri komunikaciji. To znači da nastavnik koji odgaja treba dopustiti učeniku da mu se obraća na ravnopravan način (naravno, pritom ne smije kršiti temeljna pravila pristojnosti i poštovanja), što bi se u cjelokupnom odgojnom odnosu nastavnika i učenika očitovalo kao uvažavanje. Također su dobrodošle i kompetencije poznavanja različitosti s obzirom na brojne aspekte sredine $u$ kojoj se nastavnik nalazi i individualne različitosti prema kojima je i nastao suvremeni didaktički koncept individualizacije nastave. Na nastavniku koji želi odgojno maksimizirati uspjehe jest zadaća da prepozna mogućnosti, potrebe i osobine svakoga učenika, što za sobom povlači i kompetenciju fleksibilnosti, a time kod učenika potiče autentičnost - sposobnost da učenici budu ono što jesu i da druge prihvaćaju onakvima kakvi jesu. Nastavnik odgojitelj koji posjeduje te kvalitete, odnosno profesionalne kompetencije, lakše će učenicima usaditi poželjne odgojne vrijednosti i vrline: autonomiju, slobodoumnost, temeljitost, odgovornost, moralnu zrelost, empatičnost i samopouzdanost.

Pri istraživanju čimbenika koji su nužni za obrazovanje novoga nastavnika odgojitelja, dakle nastavnika koji je aktivan graditelj znanja, koji, ukratko, posjeduje sve ranije navedene kvalitete, autori su se okrenuli modelu obrazovanja refleksivnoga praktičara, o čemu ćemo govoriti malo kasnije kao mogućnosti za nastavnike - odgojitelje novoga doba. Važno je shvatiti da profesionalne kompetencije ${ }^{55}$ olakšavaju nastavniku odgojni rad. ${ }^{56}$

Do sada smo mogli vidjeti kako su odgoj i obrazovanje u tolikoj mjeri međusobno isprepleteni da ih je praktički nemoguće odvajati. Odgoj i obrazovanje jesu društvene funkcije i potrebe koje dovode do samoodređenja. ${ }^{57}$ Kolika je, zapravo, važ-

${ }^{55}$ Za razvoj profesionalne kompetencije budućega odgojitelja nužno je: »poznavanje materije, osnovnih koncepcija, strukture i istraživanja djetetova razvoja i odgoja, poznavanje osnovnih zakonitosti djetetova učenja, prepoznavanje njegovog individualnog intelektualnog, socijalnog, emocionalnog i tjelesnog razvoja i odgoja, poznavanje različitih stilova učenja i razvijanje sposobnosti prepoznavanja i osiguravanja uvjeta za tu različitost, prepoznavanje i organiziranje povoljne sredine za učenje djeteta na temelju njegovih individualnih i grupnih interesa i motivacije, izgrađivanje komunikacijskih vještina potrebnih u interakciji s djecom, roditeljima, kolegama i ostalim profesionalcima iz njegove sredine.« M. ŠAGUD, Odgajatelj kao refleksivni praktičar, 13.

56 »Odgojni rad je u službi ostvarivanja pozitivnih društvenih ličnosti. Takav odgojni rad traži mnogo napora, dobru organizaciju, posebne programe i poznavanje specifične metodike odgojnog rada.« A. VUKASOVIĆ, Prinosi unaprijeđivanju odgojnog rada, 1.

${ }^{57}$ Usp. I. LAVRNJA, Poglavlja iz didaktike, Rijeka, 1998. 
nost odgoja i obrazovanja možemo bolje razumjeti ako se pozovemo na Platona koji je smatrao odgoj glavnom funkcijom države. ${ }^{58}$ Naime Platon je u svojoj Državi detaljno opisao kako se djeca i mladi trebaju odgajati te je dobrim odgojem smatrao onaj koji jamči održavanje pravednosti. Iako se Platonovo i suvremeno poimanje odgoja razlikuju, u obama se naglašava briga za odgojnu djelatnost. No koga danas smatramo dobrim odgojiteljem? Dobar odgojitelj jest dobar upravo iz razloga što ima dobar odnos s učenicima. Stoga je, govoreći o kompetencijama odgojitelja, točnije nastavnika, važno progovoriti i o odnosu između nastavnika i učenika. Suvremeni nastavnik odgojitelj mora biti svjestan težine lošega odnosa s učenicima jer činjenica je da: »bez dobrog odnosa naš je utjecaj na druge ili nepostojeći ili uništavajući. $\ll^{59}$ Loši odnosi između nastavnika i učenika ${ }^{60}$ vladaju u tradicionalnim obrazovnim ustanovama, pri čemu se događa da: $\gg$ nezadovoljan lošim učenicima, klasični nastavnik poseže za prisilom. Prijeti slabim ili negativnim ocjenama. No time ništa ne postiže. $\ll{ }^{61}$ Ono što se savjetuje u takvim situacijama jest da škole nauče da one moraju snositi odgovornost: »stoga bi veća kompetencija $u$ odnosima nastavnika dobro došla, osobito samim nastavnicima. (...) Djeca imaju mnoštvo kompetencija, ali jedna im nedostaje: nisu sposobni preuzeti odgovornost za kvalitetu svojih odnosa s odraslim osobama. ${ }^{62}$ I sada dolazimo do načina na koji nastavnik pokazuje svoju kompetenciju u odnosima. Ranije smo naveli da nastavnik svakako treba posjedovati kompetencije koje će mu omogućiti kvalitetno uspostavljanje odnosa. Međutim fleksibilan treba biti u situacijama koje su nepredvidive, a to su mogući konflikti koje treba znati učinkovito riješiti. Problem je što većina nastavnika smatra vlastitim porazom priznanje pogrješke u odnosu s učenikom s kojim se bilo kakav konflikt dogodio, kao da će ispasti lošiji nastavnici ako priznaju da su i sami doprinijeli lošem odnosu. Jer što je odnos? ${ }^{63} \mathrm{U}$ odnosu imamo dvije strane koje su u međusobnoj relaciji. U školskoj situaciji to su nastavnik i učenik. Iz toga razloga ne može samo i isključivo jedna strana biti kriva za konflikt, učenici su možda okidači, no odgovornost je uvijek na nastavnicima. Obje strane trebaju snositi djelomičnu odgovornost: »odgovornosti se učimo samo tako da ju preuzimamo, a djeca to trebaju slijediti. $\ll{ }^{64}$ Odrasla osoba koja radi nastavnički

\footnotetext{
${ }^{58}$ Usp. PLATON, Država, Zagreb, 1997.

${ }^{59}$ W. GLASSER, Teorija kontrole, Zagreb, 1997., 202.

${ }^{60}$ Usp. J. JUUL, Škola u infarktnom stanju: što učiniti kako bi djeci, roditeljima i nastavnicima bilo bolje, Zagreb, 2013., 47.

${ }^{61}$ W. GLASSER, Nastavnik u kvalitetnoj školi, Zagreb, 1999., 96.

${ }^{62}$ J. JUUL, Škola u infarktnom stanju: što učiniti kako bi djeci, roditeljima i nastavnicima bilo bolje, 48.

${ }^{63} \gg$ Odnosi su vid društvenih kontakata i podrazumijevaju prijateljstvo, prisnost, bliskost i povjerenje. « I. DISSING SANDAHL, Igra na danski način, 101.

${ }^{64}$ W. GLASSER, Teorija kontrole, 212.
} 
posao i koja učenika treba naučiti odgovornosti treba sama biti primjerom kako se preuzima odgovornost, jer je upravo nastavnik presudan za kvalitetan odnos. ${ }^{65}$ Dakle kako nastavnik pokazuje kompetenciju u odnosima? Tako što će nastojati razumjeti učenika, uočiti problem zbog kojega je odnos narušen i nastojati ga riješiti, samo je potrebno zapitati se gdje griješimo te o tome i porazgovarati s učenicima: >djeca u pravilu točno znaju zašto im je loše, no vjerojatno ih se nikad ne pita za to. ${ }^{66}$ Također preporuka za odgoj čiju pozadinu nalazimo u teoriji kontrole ${ }^{67}$ glasi da pri uspostavljanju kvalitetnoga odnosa, koji je nužan pri odgoju djeteta, bio taj odgoj roditeljski ili nastavnički, treba dati ljubav i toplinu, ali »radite što je moguće manje za njih i njima, a više budite s njima. ${ }^{68}$ Nastavnik odgojitelj, koji odgaja odgovornom ponašanju, mora biti odgovoran kada uspostavlja odnose s učenicima, time i učenike uči graditi dobre odnose. ${ }^{69}$

\section{Odgojiteljska umijeća}

Za uspješno poučavanje svaki nastavnik mora posjedovati umijeća. U djelu Kvalitetna škola William Glasser navodi: »uspješno poučavanje vjerojatno je najteži posao na svijetu. $\ll^{70}$ Zato ćemo sada odgovoriti na pitanje kakva su to umijeća. ${ }^{71}$ Kyriacou navodi kako su to umijeća ${ }^{72}$ koja će uspješnom nastavniku omogućiti da zna čime i kako potaknuti učenike da uče. ${ }^{73}$ Kod umijeća poučavanja imamo praktičnu sposobnost, ali i sposobnost promišljanja o praktičnom djelovanju. Tu prvu

$\overline{65} \gg$ Većina nastavnika zazire od takvih mjera jer ima osjećaj da na taj način otkriva osobnu i pedagošku slabost koja bi mogla potkopati njihov autoritet. Oni taj sukob greškom drže borbom za moć koju pod svaku cijenu žele dobiti.« J. JUUL, Škola u infarktnom stanju: što učiniti kako bi djeci, roditeljima i nastavnicima bilo bolje, 49.

${ }^{66}$ Isto, 51.

${ }^{67}$ Teorija kontrole - teorija psihijatra dr. Williama Glassera koja se temelji na izboru, učiniti bolji izbor znači imati više kontrole nad životom. Usp. W. GLASSER, Teorija kontrole, Zagreb, 1997.

${ }^{68}$ Isto, 221.

${ }^{69}$ Postoje tri načina kako možete pomoći djeci da nauče graditi dobre odnose i sva su tri međusobno nerazdvojiva. Usp. I. DISSING SANDAHL, Igra na danski način, 102.

${ }^{70}$ W. GLASSER, Kvalitetna škola, Zagreb, 1994., 25.

${ }^{71} \gg$ Nastavna se umijeća mogu opisati kao odjelite i smislene nastavničke aktivnosti koje potiču učenje.« C. KYRIACOU, Temeljna nastavna umijeća, Zagreb, 2001., 19.

$72 \gg$ Strategije kojima se nastavnici služe da bi olakšali učenicima naučiti nešto vrijedno i koje (strategije) kompetentne osobe smatraju umijećima.«Isto, 15.

${ }^{73}$ Razlika između znati što i znati kako lijepo se vidi u analogiji s igranjem tenisa. Profesionalni igrač tenisa zna kako izvesti svaki udarac, ali to ne mora značiti da će mu svaki donijeti poen i biti uspješno odigran, to umijeće igranja tenisa sastoji se, među ostalim, od promišljanja o svakom udarcu, od odluke gdje treba lopticu prebaciti i od praktične sposobnosti da taj udarac koji je zamišljen bude na koncu i dobro izveden. Isto, 13. 
sposobnost u našem sustavu zadovoljavamo već školskom praksom, dakle svi nastavnici na početku svoje karijere određeno vrijeme provode promatrajući druge nastavnike kako rade, što ih potiče da vlastitu praktičnu djelatnost ostvare kako treba. Ono što istraživači koji su proveli brojne studije o nastavnim umijećima tvrde jest da je jedno od obilježja nastavnih umijeća njihova interaktivna priroda, jer je nastava živi proces i ne može se uvijek provoditi točno onako kako je isplanirano i zamišljeno, a drugo obilježje nastavnih umijeća jest posjedovanje stručnoga znanja. ${ }^{74}$ Autor na kojega se pozivamo donosi popis glavnih nastavnih umijeća koji je nastao na temelju rada brojnih istraživača odgoja i nastavničke djelatnosti te je široko prihvaćen. Prema tomu popisu temeljna nastavna umijeća (kada je, strogo gledajući, obrazovanje u pitanju) jesu: planiranje i priprema, izvedba nastavnoga sata, vođenje i tijek nastavnoga sata, razredni ugođaj, disciplina, ocjenjivanje učeničkoga napretka, osvrt i prosudba vlastitoga rada. ${ }^{75}$ Zašto to spominjemo? Zato što govorimo o vrlo važnoj ulozi nastavnika odgojitelja ${ }^{76}$ - profesionalca koji odgaja u školi, dakle nastavnika koji odgaja uz pomoć svojih nastavničkih kompetencija u različitim nastavnim situacijama i koji jednostavno mora posjedovati ili imati tendencije razviti takva umijeća kako bi uspješno i djelotvorno radio svoj posao, a u konačnici i dobro i pravilno odgajao jer je učenicima prije svega potrebno kompetentno vodstvo. Pri tome ne smijemo zaboraviti da: »biti nastavnik znači - cijeli život i sam učiti. ${ }^{77}$ Služeći se pravilno temeljnim nastavnim umijećima, nastavnik pokazuje kvalitete koje nastavnik odgojitelj novoga doba treba posjedovati.

\section{Odgojitelj - refleksivni praktičar - mogućnost za nastavnike}

Jedna od mogućnosti za nastavnike koji žele usavršiti svoju odgojnu metodu može biti refleksivna praksa. Refleksivni praktičar ${ }^{78}$ jest odgojitelj koji pri svom radu razmišlja o svojim akcijama i pri tom mijenja način rada u skladu s ciljem do kojega želi

\footnotetext{
${ }^{74} \gg$ Znanje o gradivu, znanje o širokim načelima i strategijama organizacije nastave, znanje o nastavnim materijalima i programima vezanim za kurikulum, znanje o poučavanju pojedinih tema, znanje o učenicima, znanje o pedagoškim kontekstima, od razreda do šire društvene zajednice i znanje o pedagoškim ciljevima i vrijednostima. $\ll$ Isto, 17 .

${ }^{75}$ Isto, 24.

${ }^{76}$ Usp. A. GOLUBOVIĆ, Odgojne implikacije Kierkegaardove antropologije, 216.

${ }^{77}$ M. MATIJEVIĆ, D. RADOVANOVIĆ, Nastava usmjerena na učenika. Prinosi razvoju metodika nastavnih predmeta u srednjim školama, Zagreb, 2011., 329.

78 \Refleksivni praktičar stvara, odnosno gradi refleksivnu praksu na osnovi svog razmišljanja o njoj - prije i poslije aktivnosti i djelovanja te tijekom akcije što je karakteristika vrsnog (refleksivnog) praktičara. Mogli bismo reći da proces razvoja refleksivnog praktičara znači proces uzdizanja na metarazinu svog odgojnog djelovanja, učenja i poučavanja.« Usp. M. ŠAGUD, Odgajatelj kao refleksivni praktičar, 14.
} 
doći. Svaki nastavnik treba biti otvoren za kritike i konstruktivne prijedloge, treba biti otvoren za novitete i promjene u svom radu, treba razmišljati kako se unaprijediti i kako dati svoj maksimum. U tom smislu ide teorija refleksivne prakse: $\gg \mathrm{u}$ tom kontekstu do punog izražaja dolazi učenje kao dinamičan i kompleksan proces koji uključuje kreativno mišljenje, procjenu oko izbora odluke i istraživanja. $\ll{ }^{79}$ Nastavnik koji želi djelovati u skladu s teorijama refleksivne prakse bit će aktivan u istraživanju rješenja i različitih načina dolazaka do odgovora na praktične probleme s kojima će se susretati u praksi: »njega karakterizira 'refleksivna otvorenost', a ona se javlja kad smo voljni preispitati vlastito mišljenje i spoznati da je bilo koje stajalište do kojeg možemo doći, u najboljem slučaju, tek hipoteza o svijetu. Bez obzira na to koliko bila uvjerljiva, bez obzira na to koliko smo naklonjeni 'svojoj zamisli', ona je uvijek podložna preispitivanju i poboljšanju. $\ll^{80}$ Autori koji zagovaraju refleksivnu praksu navode kako se takav pristup temelji na akcijskom istraživanju. ${ }^{81}$ Ovdje nije potrebno da detaljno opisujemo takvo istraživanje, ali ćemo se osvrnuti na ulogu odgojitelja u akcijskom istraživanju. ${ }^{82} \mathrm{~S}$ obzirom na to da je u našem obrazovnom sustavu još uvijek dominantna drukčija orijentacija, da se nastavnike ne doživljava kao istraživače vlastitoga rada, već kao obrazovane osobe koje imaju naučen obrazac koji preslikavaju na sve moguće situacije, takav rad jednostavno ne može biti kvalitetan. Svu teoriju koju nastavnici odgojitelji nauče moraju znati praktično primijeniti, preispitati, kritički sagledati. No čemu još služi refleksivna praksa? Pa upravo onomu o čemu smo pisali ranije: »pomoću refleksivne prakse odgajatelji razvijaju svoje profesionalne kompetencije te im ona daje uvid u godinama primjenjivanu praksu i rutinu. $\ll{ }^{83}$ Naš zaključak jest da svaki nastavnik treba njegovati potrebu za razvijanjem i jačanjem vlastitih kompetencija, za stalnim traženjem i usavršavanjem jer, kako kaže poslovica, učiš dok si $z ̌ i v$ i nikada ne treba odustati od potrage za novim i boljim rješenjima. Tomu nas također poučava filozofija i njezine metode; polazeći od metoda znanosti odgoja i

\footnotetext{
${ }^{79}$ Isto, 14.

${ }^{80}$ Isto, 15.

${ }^{81}$ Akcijsko istraživanje - istraživanje i unaprjeđivanje procesa učenja i poučavanja koje se javlja kao opozicija tehničkom i racionalnom (tradicionalnom) modelu pripreme odgojitelja. Isto, 16.

${ }^{82}$ Osobna i socijalna motivacija u velikoj mjeri određuju kvalitetu sudjelovanja odgojitelja u akcijskom istraživanju: »odgajatelji koji participiraju u akcijskim istraživanjima zapravo sudjeluju u intenzivnom programu cjeloživotnog učenja, oni stvaraju nužne pretpostavke za takvo učenje budući da refleksijom prakse razvijaju kapacitete koji će im omogućiti učinkovitu ili produktivnu praksu. Razvijaju kritičko mišljenje, angažirano slušanje i gledanje djeteta, komunikacijske vještine, učenje uz pomoć kolega i slično.« Isto, 36 .

${ }^{83}$ Isto, 38.
} 
obrazovanja, navode nas na istraživanje i rasvjetljavanje svakoga mogućega kamena spoticanja. ${ }^{84}$

Nadalje odgojiteljski profil nastavnika uključuje i korištenje filozofskom literaturom i praksom. ${ }^{85}$ Koja je uopće poveznica filozofije i odgoja? Činjenica je da se filozofijom odgoja nije bavio velik broj filozofa, $\mathrm{u}$ filozofskoj literaturi samo se usputno mogu uočiti njihove ideje i stavovi koji se odnose na odgoj i obrazovanje. Iako dakle postoje filozofi koji nisu filozofi odgoja u strogom smislu te riječi, njihova su promišljanja o odgoju vrlo značajna. ${ }^{86} \mathrm{O}$ poveznici između filozofije i odgoja možemo govoriti već od antičkih vremena. Točnije - od vremena Sokrata i Aristotela. Postoje naime sokratovske i aristotelovske odgojne perspektive. Sokrat, kao jedan od najpoznatijih antičkih filozofa i učitelja (tj. odgojitelja) smatrao je filozofiju moralnom odgojiteljicom jer ona propituje druge radi njihova osobnoga napredovanja. »Sokrat je imao originalan pristup učenju i poučavanju, a to osobito vrijedi kada je riječ o moralnim poukama (koje su po njemu najvažnije). Njegov je stav da znanje vodi krjeposti/vrlini (dakle, obrazovanje ima odlučujuće značenje za odgoj). $\ll^{87}$ Svrha filozofije za Sokrata bio je odgoj te moralno usavršavanje sebe i drugih, što je bio i ostao krajnji cilj filozofije odgoja. Smatrao je da je filozofija kao disciplina upravo ona koja odgaja. ${ }^{88}$ Njegova metoda bila je usmjerena na osvješćivanje znanja, smatrao je da znanje odgaja te ju je vodio putem dijaloga u kojima nikad nije nudio gotove odgovore. Sokratovski pristup počiva na načelu upoznaj samoga sebe jer je Sokrat smatrao da istina, koja je jedna i apsolutna, počiva u svima nama i, da bismo ju spoznali, moramo ju pronaći u sebi. No s obzirom na to da mi živimo $\mathrm{u}$ sjeni velikih tradicija uglavnom smo indiferentni prema istinskom djelovanju, a posebice djelovanju u moralnoj sferi. ${ }^{89}$ Aristotelovski odgojni pristup održao se u mnogim segmentima i do današnjih dana, a na jezičnoj razini najbolje ga izražava sintagma $\gg$ odgoj i obrazovanje «, pri čemu se misli na $\gg$ moralni odgoj «i obrazovanje $^{90}$, odnosno suvremena filozofija koja se bavi rearistotelizacijom etike vrlina očituje se u proučavanju emocija i karaktera s obzirom na moralnost. ${ }^{91}$ Aristotel je

\footnotetext{
${ }^{84}$ Usp. V. STRAHOVNIK, Some Aspects of Epistemic Value and Role of Moral intuitions in Ethics Education, u: Metodički ogledi 21(2014.)2, 35-51.

${ }^{85}$ Usp. J. MARINKOVIĆ, Metodika nastave filozofije, Zagreb, 2008.

${ }^{86}$ Usp. A. GOLUBOVIĆ, Odgojne implikacije Kierkegaardove antropologije.

${ }^{87}$ Isto, 217.

${ }^{88}$ Usp. isto, 215.

${ }^{89}$ Usp. Ž. SENKOVIĆ, Praxis »nakon vrline $\ll, 631$.

${ }^{90}$ Usp. M. POLIĆ, Odgoj i filozofija u suvremenom društvu, Zagreb, 2006., 16.; ARISTOTEL, Nikomahova etika, Zagreb, 1982.

${ }^{91}$ Usp. S. RADIĆ, Dva različita pristupa u rearistotelizaciji suvremene etike, 645.
} 
smatrao da je najvažniji moralni odgoj za koji država odgaja svoje građane, a odgojitelji koji obrazuju djecu zaslužuju više priznanja nego roditelji koji su im poklonili samo život; jer ovi su im pružili samo život, a oni drugi i uspješan život. ${ }^{92}$ On je mišljenje podijelio na teorijsko i praktično, analogno dvjema vrstama sposobnosti koje čovjek ima, te je smatrao da ih se treba objediniti u moralnom odgoju. Tvrdio je da za moralno djelovanje nije dovoljno da istina bude u razumu, već da je potrebno i moralno ispravno htijenje, odnosno volja za moralno ispravnim djelovanjem na koje država treba građane odgojno navikavati, što je povezivao $s$ djelovanjem u skladu s vrlinama, odnosno ljudskim karakterom kao nositeljem tih vrlina. ${ }^{93}$ Slijedeći Aristotela i Platona, nastala je i disciplina etika vrlina ${ }^{94}$, za koju ih drže utemeljiteljima, a svaka moderna inačica i dalje pokazuje da su njezini korijeni u starogrčkoj filozofiji (što vidimo ponajviše iz suvremenih pristupa moralu koji preslikavaju aristotelovsku etiku u modernitet te Aristotelove postavke o vrlinama shvaćaju kao bitne postavke morala današnjice). ${ }^{95}$ Dakle vidljivo je da suvremene rasprave o odgoju, intelektualnom i moralnom, svoje korijene vuku još iz antičkih vremena, kao i da su i antički filozofi veliku važnost pridavali odgojnoj vrijednosti same filozofije i odgoju općenito, što ćemo u nastavku potkrijepiti suvremenijim primjerima.

Naime jedan suvremeni kanadski profesor filozofije napisao je posvetu u svojoj knjizi u kojoj govori o korištenju filozofijom u svakodnevnim situacijama i rješavanju svakodnevnih problema koja glasi: » za sve one koji su oduvijek znali da je filozofija korisna, ali nisu znali reći za što. ${ }^{96}$ Zato ćemo se u ovom poglavlju osvrnuti na prednosti korištenja filozofskom literaturom i praksom u odgojnom procesu, a posebice u suočavanju s problemima, pri čemu dolazi do izražaja kvaliteta empatije koju je nemoguće ne povezati s moralom (suvremeni filozofi pozivaju da se u pristupima moralu oživi tradicionalna aristotelovska etika ${ }^{97}$. No vratimo se sada na rješavanje problema $u$ odgojnoj situaciji. Činjenica je da svaki problem mora imati i rješenje, a ono što će nam savjetovati osoba koja se bavi filozofijom jest, naravno, da na tom problemu radimo filozofski ${ }^{98}$. To znači koristiti se misaonim

\footnotetext{
${ }_{92}$ Usp. ARISTOTEL, Nikomahova etika, Zagreb, 1982.

${ }_{93}^{93}$ Usp. S. RADIĆ, Dva različita pristupa u rearistotelizaciji suvremene etike, 646.

${ }^{94}$ Usp. Virtue Ethics, u: Standford Encyclopedia of Philosophy, dostupno na: https://plato.stanford. edu/entries/ethics-virtue/ (26. 4. 2019.)

${ }_{95}$ Usp. S. RADIĆ, Dva različita pristupa u rearistotelizaciji suvremene etike, 646.

${ }^{96}$ Usp. L. MARINOFF, Platon, a ne prozak! Primjena vječnih mudrosti na svakodnevne probleme, Zagreb, 2012.

${ }^{97}$ Usp. S. RADIĆ, Dva različita pristupa u rearistotelizaciji suvremene etike, 646.

98 »Radeći filozofski na svom problemu, pronaći ćete otvoren, duboko utemeljen i trajan način suočavanja sa svim s čime ćete se morati suočiti, i sada i ubuduće. Platon, a ne sredstva za smirenje.« L. MARINOFF, Platon, a ne prozak!, 20.
} 
eksperimentima koji učenike mogu potaknuti na angažirano mišljenje, poboljšati im razumijevanje i potaknuti kritičku refleksiju. ${ }^{99}$ Dakle uputa je da se korištenjem filozofijom, odnosno mudrošću filozofa uoči način na koji se možemo nositi s problemima. Ono što nam se čini kao dobar način koji se može preslikati na nastavnika odgojitelja koji radi u školi i suočava se svakodnevno s bezbroj malih, velikih, teških ili lakih problema jest tzv. filozofsko rješavanje problema u pet koraka, a koraci jesu: problem, emocije, analiza, kontemplacija i ravnoteža. Prva dva koraka ljudima dolaze prirodno, nastavnik će vrlo lako u odgojnoj situaciji opaziti problem, a i emocije vezane uz problem bit će jasno predočene. Za analizu i kontemplaciju dobro se savjetovati s kolegama odgojiteljima kako bi u konačnici postigli ravnotežu, točnije uputa glasi: $\gg$ kad se s problemom suočavate na filozofski način, prvo ga morate identificirati. Drugo, morate se suočiti i s emocijama koje je problem potaknuo. U trećem koraku, analizi, nabrajate i procjenjujete mogućnosti koje su vam na raspolaganju za rješavanje problema. $U$ četvrtoj fazi vraćate se korak natrag te $s$ novostečenom perspektivom kontemplirate svoju situaciju. Konačno, postižete stanje ravnoteže. Shvaćate bit vlastitog problema i spremni ste za prikladno i opravdano djelovanje. ${ }^{100}$ Dakle navedenim rješavanjem problema u pet koraka može se koristiti svatko, u svakom trenutku. No s obzirom na to da govorimo o odgoju i odgajanju, želimo istaknuti kako će nastavnici koji su upoznati s filozofijom i mogućnostima koje ona nosi za odgojne situacije ${ }^{101}$, dakle s filozofskom misli značajnih filozofa, odgojitelji koji su i sami filozofski uzori, lakše i brže osmišljavati raznorazne načine djelovanja u odgojnim situacijama. Taj ponuđeni način rješavanja problema svakako mogu prenijeti i na učenike kojima su učenje i sposobnost ovladavanja poteškoćama vrlo značajni. ${ }^{102}$ Nastavnik koji se koristi filozofijom shvaća njezinu važnost i vrijednost, korištenjem filozofijom odgaja i sebe i druge jer, kao što je govorio Buda: »stolari oblikuju drvo, streličari oblikuju strijele, a mudri oblikuju same sebe.« Nastavnik koji je oblikovao sebe znat će oblikovati i druge, a to je i bit odgojiteljskoga posla i način za postizanje svih kvaliteta potrebnih odgojitelju novoga doba: »čovjek je biće koje se stalno razvija, oblikuje, usavršava. Za razliku od onih društvenih znanosti koje istražuju kakvi su ljudi danas, pedagogija je usmjerena prema budućnosti, tražeći odgovor na pitanje kakvi bi oni mogli i trebali biti. ${ }^{103} \mathrm{U}$ osnovi različite, pedagogija i filozofija (odgoja) u suradnji mogu

\footnotetext{
${ }^{99}$ Usp. V. STRAHOVNIK, Some Aspects of Epistemic Value and Role of Moral intuitions in Ethics Education, 46.

${ }^{100}$ Isto, 68.

${ }^{101}$ Usp. isto, 47.

${ }^{102}$ Usp. I. DISSING SANDAHL, Igra na danski način, 42.

${ }^{103}$ A. VUKASOVIĆ, Prinosi unaprijedivanju odgojnog rada, 7.
} 
ostvariti značajne rezultate, osobito sagledavajući odgoj kao najvažnije društveno pitanje našega vremena.

\section{Filozofija odgoja}

»Moralno razmišljanje nije samo specijalizirani predmet za one koji bi se željeli posvetiti višem stupnju studija filozofije, nego je to bitni dio bilo kakva odgoja dostojna toga imena. $\ll{ }^{104}$

Filozofiju odgoja vrlo je teško definirati, ne postoji prihvaćena definicija iz razloga što se stručnjaci iz različitih područja ne mogu dogovoriti kako definirati nešto što proizlazi iz odgoja koji je i sam po sebi višeznačan. $U$ radu smo prikazali stajališta i teze glavnih predstavnika filozofije odgoja te možemo sa sigurnošću reći da je filozofija odgoja ${ }^{105}$ disciplina koja propituje bit odgoja i kako su odgoj kao ključan čimbenik ljudskoga života prepoznali mnogi: jedan od suvremenih divova filozofije odgoja John Dewey zastupa stav da je odgoj najviši čovjekov cilj iznad kojega nema višega cilja. ${ }^{106} \mathrm{Da}$ je tomu tako potvrđuju i prethodni dijelovi ovoga rada u kojima su detaljno razrađene kompetencije i vještine nastavnika odgojitelja, koje služe upravo razvijanju odgojenikovih moći i izgrađivanju osobnosti, stjecanju vrlina, odnosno emancipiranju odgojenika. O navedenome govorimo u potonjim dijelovima i pri tome tvrdimo da obrazovanje djece i mladih mora poticati njihovu maštu, suosjećanje, samosvijest, društvene vještine i emocionalno zdravlje jer su to sve sastavni elementi cjelovita razvoja djeteta koji povećavaju vjerojatnost dobroga, moralnoga odgoja o kojem i govore brojni filozofi na koje smo se pozivali.

Dakle profil nastavnika odgojitelja koji nudimo prožet je filozofskim smjernicama proizišlima iz filozofije općenito, a posebice iz samostalne discipline unutar filozofije, a to je filozofija odgoja čiji je: »krajnji cilj biti kompletno i potpuno ostvarena osoba. $\ll 107$

${ }^{104}$ F. SAVATER, Etika za Amadora, Zagreb, 1998., 12.

${ }^{105}$ Naravno, glavna se rasprava vodi između filozofa odgoja i pedagoga. Naime i jedni i drugi tretiraju odgoj kao svoje povlašteno mjesto. O tome je još davne 1993. godine govorio Milan Polić u svojoj knjizi Kfilozofiji odgoja jer je u to vrijeme filozofija odgoja bila jedna od najmlađih disciplina. O filozofiji odgoja piše i William Frankena. On je objedinio stajališta i temeljne odgojne aspekte istaknutih filozofa u zborniku Philosophy of Education. Naime Frankena naglašava razliku između filozofije u odgoju i filozofije za odgoj, napominje kako je sam odgoj poliznačan te da on pod disciplinom o odgoju misli na, među ostalim, poučavanje subjekta koji se mora izgraditi. Što se tiče definicije odgoja, filozof iz toga područja Milan Polić u svojim radovima govori o definiranju odgoja te navodi kako se većina autora ipak slaže da je odgoj djelatnost kojom se razvijaju čovjekove moći. Usp. M. POLIĆ, Odgoj i svije(s)t, Zagreb, 1993., 20.; W. FRANKENA, Philosophy of Education, 1-19.

${ }^{106}$ Usp. A. GOLUBOVIĆ, Odgojne implikacije Kierkegaardove antropologije, 215.

${ }^{107}$ Isto, 215. 


\section{Odgoj za emancipaciju učenika}

O vrijednosti filozofije u odgajanju govorili smo ranije, a unutar toga želimo još istaknuti i kako je vrlo važno i potrebno pri odgoju koji ide u smjeru autonomije i slobodoumnosti iskorijeniti negativne odgojne utjecaje, često prisutne $u$ obliku idola, tj. predrasuda. Davno je već Bacon govorio o predrasudama koje ometaju čovjekov dolazak do spoznaje i znanja. No što su, zapravo, idoli i što $\operatorname{Bacon}^{108} \mathrm{~s}$ njima želi poručiti? Bacon tvrdi: »Vere scire est per causas scire $\ll{ }^{109}$ - tj. da bismo došli do spoznaje, moramo opažati prirodu. ${ }^{110} \mathrm{~A}$ kako ćemo to činiti ako su nas okovale brojne predrasude? Te predrasude, kao što znamo, naziva idolima i nabraja ih četiri vrste. ${ }^{111}$ Borbom protiv idola želi se poručiti da sve treba preispitati i utemeljiti na iskustvu, jer predrasude o kojima je Bacon govorio prisutne su i danas. ${ }^{112}$ Nastavnik, kojega smatramo krjeposnom odraslom osobom, ali ne i nepogrješivom, dužan je izbjegavati ih u svom radu kako bi spriječio mnoge štetne utjecaje na svoje učenike. Dužan je to činiti iz razloga što djeca i adolescenti često štete drugima u svojoj okolini, u prvom redu jer je njihovo razumijevanje onoga što je štetno ograničeno i če-

108 >Bacon raspravlja o učinkovitoj upotrebi uma u istraživanju prirode, što se svodi na uviđanje zapreka koje se postavljaju ljudskom umu, a koje je Bacon nazvao idolima, na nastojanje da se one iskorijene.« E. BANIĆ-PAJNIĆ, Filozofija renesanse, Zagreb, 1996., 369.

${ }^{109}$ Lat. istinita spoznaja jest spoznaja uzroka.

${ }^{110}$ Povratak prirodi zagovara i J. J. Rousseau. Usp. J. J. ROUSSEAU, Emil ili o odgoju, Beograd, 1989.

$111 \gg 1$. Idola tribus (idoli plemena), zajedničke predrasude čovječanstva općenito, a podrijetlo im je $\mathrm{u}$ naravi ljudskog duha, a sastoje se u tome da ljudi prosuđuju stvari ne po onom što one jesu, nego po odnosu koji imaju prema njima. Ljudski duh je, pokvareno zrcalo. Do ovih predrasuda dolazi zato jer iskrivljujemo sliku. Primjer ovakvih idola bilo bi vjerovanje u astrologiju ili snove. U njima ćemo tražiti opravdanje za ono u što želimo vjerovati, a zanemarit ćemo ono u što ne želimo vjerovati čak i ako je realnije. 2. Idola specus (idoli spilje), predrasude svakog pojedinca kojima robuje, a dolaze od njegova sebična stanja, temperamenta, karaktera, ukusa, odgoja, socijalnih funkcija i navika. To je vlastita mala spilja kamo ne dospijeva prirodno svjetlo. Dakle, na temelju vlastitih uvjerenja procjenjivat ćemo okolinu. 3. Idola fori (idoli trga), predrasude koje proizlaze iz socijalnih odnosa, osobito jezika. Duh je obično zaveden riječima koje upotrebljava i koje ničemu ne odgovaraju te izražavaju zbrkane ideje pa su izvor ekvivokacija. Ove predrasude će nas okovati kada dođe do pogreške u komunikaciji i jednostavno krivo protumačimo rečeno. 4. Idola theatri (idoli kazališta), predrasude koje proizlaze od teorija i filozofskih sistema, koji su kao kazališni komadi koje filozofi postavljaju na pozornicu. Naime, poštujući neki autoritet prihvaćamo sve što taj autoritet misli i radi, pa tako i njegove greške.Tako u kazalištu autoritet glumaca stvara atmosferu, za koju publika misli da je stvarna, a u stvari je umjetna.« Usp. I. MACAN, Francis Bacon, filozofija.org, dostupno na: https://www.filozofija.org/wpcontent/uploads/Povijest_fil.org/Moderna_pdf/Bacon-final.pdf (22. 8. 2018.)

$112 \gg$ Danas se većina odgoja djece odvija u okviru obitelji i u školama. Zato mi odrasli trebamo biti svjesni stereotipa, predrasuda i naracija s kojima se djeca susreću u okolinama unutar kojih se kreću. « I. DISSING SANDAHL, Igra na danski način, 95. 
sto pogrješno. ${ }^{113}$ Nastavnik treba neprestano upozoravati učenike na predrasude i dati im uvid u one koje trebaju izbjegavati. ${ }^{114}$ Drugim riječima, nastavnikov je zadatak pomoći i ohrabriti te voditi učenike $\mathrm{k}$ ispravnom promišljanju i preispitivanju, $\mathrm{k}$ samostalnosti u prepoznavanju pogrješnih ponašanja (a ne ograničavati njihova iskustva i propisivati im pravila). ${ }^{115} \mathrm{U}$ poveznici s tim ide i odgoj i obrazovanje za vrijednosti ${ }^{116}$, jer nastavnik koji odgaja u skladu s vrijednostima, tj. koji priprema mlade za svijet odraslih, mora i sam živjeti sokratovski, dakle u skladu s vrijednostima kojima želi poučiti svoje učenike. On ih poučava, ali i potiče u razvijanju dobrih navika te im pomaže iskorijeniti, odnosno upozoriti na one negativne, loše navike o kojima govori Baconova teorija idola.

Osim toga za izgradnju uspješnoga nastavnika odgojitelja važno je i korištenje univerzalnom metodom poučavanja, odnosno nastavnik bi, uz ostale kvalitete koje

${ }^{113}$ Usp. Virtue Ethics, u: Stanford Encyclopedia of Philosophy, dostupno na: https://plato.stanford. edu/entries/ethics-virtue/ (26.4.2019.)

${ }^{114}$ Ako sad preslikamo idole na odgojiteljski posao vrlo lako možemo primjerima potkrijepiti što to odgojitelj, čiji profil nudimo, treba izbjegavati pri svom odgojiteljskom radu. Idole plemena odgojitelj će izbjeći na taj način što ne će propitivati učeničku inteligenciju na temelju ocjene koju učenik ima, ne će propitivati znanje na temelju nediscipliniranoga ponašanja, ne će obezvrijediti cijeli razred zbog jednoga učenika koji je problematičan. Zašto se te predrasude zovu idolima plemena? Pa zato što je Bacon smatrao da su one, jednostavno, u ljudskoj prirodi, kao što kaže izreka: »Ljudi smo - griješimo.« Ono što je važno jest da i ako počinimo pogrješku, da je uočimo i ispravimo, da ne činimo zlo, da ne budemo pokvarena zrcala. Predrasude pećine u odgojiteljskom su smislu poučavanje »kao da nijedan drugi predmet ne postoji «. To je česta nastavnička pogrješka, što se ne može zamjeriti jer su neki nastavnici toliko entuzijastični i vole svoj posao da jednostavno žele sve znanje koje imaju prenijeti na učenike, što ponekad rezultira pretjerivanjem s obvezama koje učenici uz sve ostale predmete ne stižu ispunjavati. Što je još gore, dovodi ih se do toga da zamrze predmet kojim ih se preopteretilo. Odgojno time nismo ništa postigli. Nadalje predrasude trga na neki su način igra $\gg$ gluhog telefona $\ll$, nerazumijevanje, nesporazumi i zbrka. Odgojitelji i učenici po mnogočemu se nalaze na različitim razinama, različitih pogleda na svijet i različitih shvaćanja, no to ne smije biti prepreka u odgoju. Pogrješaka u razumijevanju ne bi trebalo biti, zato se treba paziti na izražavanje, razgovarati s učenicima, uočavati probleme i rješavati nesuglasice proizišle iz buke u komunikaciji. Svaka priča ima dva kraja i oba treba sagledati. Predrasude kazališta jesu predrasude autoriteta. U odgojnom smislu autoritet nije loš, autoriteta treba biti, ali je problem ako odgojitelj nema sve kompetencije i nastavnička umijeća o kojima smo govorili ranije i jednostavno nije primjer kakav bi trebao biti, a učenici nisu sposobni napraviti odmak, nego prihvaćaju sve što on radi, pa tako i njegove pogrješke. Tomu u odgoju nema mjesta. Trebamo paziti kakav ćemo autoritet biti, ispraviti vlastite pogrješke kako ih netko ne bi ponovio za nama. U srži Baconovih idola leži pouka kako nastavnik koji sam izbjegava idole može uspješno, dakle vlastitim primjerom, poučiti učenike da također čine isto.

${ }^{115}$ Usp. Montessori metoda, dostupno na: http://www.montessori.edu/ (20. 1. 2019.)

${ }^{116}$ Usp. V. RAKIĆ, S. VUKUŠIĆ, Odgoj i obrazovanje za vrijednosti, u: Društvena istraživanja 19(2010.)4-5., 771-795. 
smo naveli i objasnili i koje su ponajprije vezane uz odgoj, trebao raditi na tome da bude nastavnik emancipator ${ }^{117}$, što je povezano s obrazovanjem. Kako se to postiže? Nastavnik koji želi emancipirati svoje učenike treba znati ključnu razliku između znati i razumjeti, treba, drugim riječima, znati prepustiti učenicima prostor za razmišljanje i učenje. Takav je nastavnik emancipator. ${ }^{118}$ To se vrlo lako može shvatiti uz pomoć analogije učenja materinskoga jezika. Dijete koje usvaja riječi koje čuje usvojit će ih brže i lakše te će bolje shvatiti njihov smisao ako ih je samo čulo i usvojilo, nego kada mu ih roditelji uporno nameću. ${ }^{119}$ No što točno radi nastavnik emancipator i kako je to povezano s vrlinama koje nastavnik odgojitelj treba posjedovati? On emancipira učenika da rabi vlastitu inteligenciju, da sam shvati nešto što mu nastavnik nije pojasnio i ta metoda naziva se univerzalnim poučavanjem. ${ }^{120}$ $\mathrm{U}$ tom načinu korištenja metodom univerzalnoga poučavanja dolaze do izražaja vrline autonomije i samostalnosti unutar kojih se također može iskoristiti filozofija, odnosno njezina težnja kritičkom promišljanju i propitivanju, kao i postavljanju problema u središte poučavanja. Rješavanje problema pak doprinosi organizaciji

${ }^{117}$ Iza te značajke krije se priča o profesoru na jednom nizozemskom sveučilištu iz 1818. godine. Naime priča glasi kako profesor J. J. odlazi raditi na sveučilište na kojem velik broj studenata nije znao francuski jezik, a on nije uopće znao nizozemski. Na njegovu sreću te godine izlazi dvojezično izdanje jedne knjige koju je profesor podijelio svojim učenicima i od njih je zatražio da nauče taj francuski tekst. Ono što je uslijedilo, autor na kojega se pozivamo nazvao je manjim filozofskim eksperimentom. Naime, kada su učenici prepušteni sami sebi ipak došli do određenih spoznaja i shvaćanja teksta (dakle uspjeli su razumijeti tekst), učitelj J. J. u potpunosti je promijenio svoje mišljenje: »do tada je vjerovao u ono u što vjeruju svi savjesni profesori. Da se prevažni posao učitelja sastoji od toga da svoje spoznaje prenese na učenike kako bi ih za koji stupanj uzdignuo bliže vlastitoj učenosti. On je, kao i učenici, znao da nije riječ o tome da se učenike kljuka spoznajama tjerajući ih da to ponavljaju kao papige, ali isto tako da treba izbjegavati stranputice na kojima se gube duhovi koji još nisu sposobni razlikovati bitno od sporednoga i načelo od posljedice. Ukratko, posao učitelja bio je da objašnjava, poučavati je značilo, $u$ istome mahu, prenijeti spoznaje i oblikovati duhove vodeći ih. No, odjednom se, sasvim slučajno, pojavilo zrno pijeska u stroju. Učitelj svojim 'učenicima' nije dao nikakva objašnjenja o temeljnim elementima jezika. Nisu li učiteljeva objašnjenja, dakle, bila suvišna? «Isto, 12 .

${ }^{118}$ Ono što je zaključio profesor iz priče jest da treba okrenuti logiku objašnjavanja: »objašnjavatelj treba nesposobnoga, a ne obrnuto.« Činjenica koju možemo opaziti jest da su studenti naučili bez učitelja koji im je objašnjavao, što znači da ako se dogodilo tada, može se dogoditi uvijek: »dakle, oni nisu naučili zbog učiteljeva znanja. On je bio učitelj zahvaljujući zapovijedi koja je njegove učenike zatvorila u krug iz kojeg su mogli izaći jedino sami, ostavljajući svoju učiteljsku inteligenciju po strani kako bi njihova učenička inteligencija bila zaokupljena inteligencijom knjige. Tako su se razdijelile dvije funkcije koje povezuju praksu učitelja koji objašnjava - funkcija znalca i funkcija učitelja.«Isto, 21.

119 »Razumijevanje je ono što dijete ne može steći bez učiteljeva objašnjenja, što će steći utoliko kasnije ukoliko mu učitelji ne ponude materiju koju treba savladati, i to u određenom sustavu napredovanja.«Isto, 14.

${ }^{120}$ Univerzalno poučavanje postoji od početka svijeta uz sve ostale metode objašnjavanja. Isto, 25. 
znanja te omogućuje učenicima da nadilaze svoja duboko ukorijenjena uvjerenja. ${ }^{121}$ Da učenike treba poučavati samostalnosti, autonomiji i emancipaciji tvrdila je i poznata učiteljica Maria Montessori: »nikad nemojte pomagati djetetu u onome što može obaviti samo. $\ll{ }^{122}$ To znači da se rješavanje problema ne prakticira u mjeri u kojoj bi se moglo i trebalo koristiti. Nastavnici su i dalje shvaćeni kao prenositelji znanja koji moraju znati apsolutno sve, a njihovi učenici kao papige koje to znanje trebaju ponavljati. Obrazovni sustav treba nastavnike koji će to promijeniti jer učenike treba navoditi da sposobnosti naučene u školi primjenjuju u svakodnevnom životu. Tako bi obrazovanje postalo učinkovitije, povezali bi se škola i život ${ }^{123}$, što danas još uvijek nije čest slučaj. Danas se često ide protiv odgoja i obrazovanja za vrijednosti, a učenike se izlaže proturječnim i zbunjujućim porukama. ${ }^{124}$

\section{Zaključne misli}

»S ljubavlju pa i obrazovanošću raste i čovjekova odgovornost za budućnost, pa stoga najviše što jedan odgajatelj za nju može učiniti jest da obrazuje u ljubavi.« ${ }^{125}$

U radu, koji smo Vam izložili, odgojitelj je glavni junak (ove) priče. Obraćajući se izravno nastavnicima odgojiteljima i svima onima koji to žele biti, sve rečeno možemo zaključiti i riječima Williama Glassera, pokretača projekta Kvalitetna škola: »dio ste novog procesa. Neće biti lak, ali je moguć. Nagrada će vam biti to što ćete vi i vaši učenici početi uživati u zajedničkom radu i što će se silno poboljšati kvaliteta vašeg i njihovog života. $\ll{ }^{126}$ Sada ćemo s pomoću primjera pokazati na koji način nastavnik, koji odgaja, treba biti spreman na prilagođavanje u svakoj mogućoj situaciji, tj. treba biti spreman poduzimati konkretne korake kako bi postao odgojitelj primjeren našemu dobu i potrebama, odnosno kako bi kvalitetno obavljao svoj posao. Radi toga izdvajamo Aristotelov primjer s lađom. ${ }^{127} \mathrm{U}$ primjeru se spominje lađa koja putuje iz luke u luku i prevozi važan i težak teret, no usred putovanja iznenadi ju oluja. Jedini način da se posada spasi jest da se teret izbaci u more. U toj situaciji zapovjednik lađe našao se pred problemom (dvojbom) koji treba brzo

\footnotetext{
${ }^{121}$ Usp. V. STRAHOVNIK, Some Aspects of Epistemic Value and Role of Moral intuitions in Ethics Education, 35-51.

${ }^{122}$ Montessori metoda omogućuje djetetu spontano učenje otkrivanjem. Dostupno na: http://www. montessori.edu/ (20. 1.2019.)

${ }^{123}$ Usp. W. GLASSER, Nastavnik u kvalitetnoj školi, Zagreb, 1999., 68.

${ }^{124}$ Usp. V. RAKIĆ, S. VUKUŠIĆ, Odgoj i obrazovanje za vrijednosti, 772.

${ }^{125}$ M. POLIĆ, Odgoj i svije(s)t, 79.

${ }^{126}$ W. GLASSER, Nastavnik u kvalitetnoj školi, 45.

${ }^{127}$ Usp. F. SAVATER, Etika za Amadora, 38., 44-46.; ARISTOTEL, Nikomahova etika, Zagreb, 1982.
} 
riješiti, odnosno treba odlučiti što učiniti. Oluja je nešto što mu se zbilo, nešto što nije mogao spriječiti i znati da će mu se dogoditi, ali on je slobodan odlučiti što će poduzeti u odnosu na zatečenu situaciju. Gotovo uvijek imamo mogućnost izbora: »bolji su izbori dostupni ako možemo naučiti kako ih primijeniti. $\ll{ }^{128} U$ takvoj situaciji, možda manje burnoj od oluje, nalazi se odgojitelj gotovo svakodnevno u nastavi. Ne može sve u svakom trenutku isplanirati i predvidjeti, ali bi trebao biti dovoljno spretan i slobodan da se zna u svakoj od takvih nepredvidivih, neobičnih situacija snaći i poduzeti konkretne korake, kao i spriječiti činjenje štete svojim učenicima. Treba znati spriječiti štetne utjecaje koji proizlaze iz njegovih loših odluka i postupaka. Treba znati između više načina i izbora primijeniti onaj koji bi trebao biti najpravedniji i najkorisniji za sve sudionike nastavnoga procesa.

Dakle zamislimo nastavnika kao zapovjednika u oluji, koji nosi velik teret odgovornosti na svojim leđima. On je taj koji u svakom trenutku treba biti spreman donositi odluke o postupcima kojima će upravljati svojom lađom (razredom) imajući u vidu da pritom ne našteti svojim učenicima, već da ih spasi od oluje. Nastavnik je osoba koja se u svakom trenutku nastavnoga procesa mora znati prilagoditi situaciji i učenicima, no pritom ne smije zanemariti sve ranije navedene vrline (umijeća i kompetencije) koje bi trebao posjedovati i primjenjivati. Naravno, nemoguće je predvidjeti kako će svaki učenik reagirati s obzirom na to da je »svaki učenik svijet za sebe $\ll{ }^{129}$, ali upravo ta specifičnost nastave može se regulirati modernizacijom nastave i odgojiteljevom izvrsnošću. Takvi odgojitelji budimo i ispunimo svrhu i cilj odgoja budućnosti. Škole se okreću novim programima rada, potiču nastavnike da se mijenjaju u korist novim obrazovnim sustavima i takve prilike treba iskoristiti. Profil suvremenoga nastavnika odgojitelja zadovoljavaju »nastavnici koji kao neposredni graditelji škole budućnosti, pored obrazovanja iz prošlosti, imaju i svoje vizije o budućnosti nastave. ${ }^{130} \mathrm{Uz}$ primarnu zadaću koju svaki nastavnik ima, a to je, naravno, poučavanje, on treba biti otvoren za nove izazove i stalno postavljanje pitanja. Tu nam vrlo korisna može biti filozofija, koja nas potiče na traganje za odgovorima, njezina je bit da nas oslobodi predrasuda i otvori nam nove vidike. $U$ konačnici, postavljati si pitanja i propitivati vrijedno je zato što je: »pravi cilj obrazovanja osposobiti čovjeka da može sam nastaviti postavljati pitanja. «131

\footnotetext{
${ }^{128}$ W. GLASSER, Teorija kontrole, 13.

${ }^{129}$ P. SKOK, Učenik u suvremenoj nastavi: jučer, danas, sutra, Lučko, 1997., 61.

${ }^{130}$ Isto, 104.

${ }^{131}$ M. CREIGHTON, Thoughts on Education: Speeches and Sermons, London, 1902., dostupno na: https://en.wikipedia.org/wiki/Mandell_Creighton (15.1.2019.)
} 


\section{SOME THOUGHTS ON THE PROFILE OF AN EDUCATOR}

\section{Aleksandra GOLUBOVIĆ* - Petra DOMAĆINOVIĆ ${ }^{* *}$}

Summary: In this paper we want to point to new trends in analyzing the role of educators, such that are fitting for our times. By educator we mean a trained professional, an expert whose job is to sensitize the public to particular issues and apply relevant educational theories and practices on all levels of the educational system. Educators should follow current developments in their field of study for the whole duration of their professional lives. This is especially true in the fields of pedagogy, psychology, didactics and philosophy of education. To that end, we have attempted to put the educator in the center of our research. The imperative of an educator is continuous professional self-development; therefore, our profile encompasses all the requirements that a $21^{\text {st }}$ century educator needs to meet. Such an educator must follow the development of all key competencies important for educational work in the contemporary school settings, which should be based on acquiring new knowledge, skills and abilities, as well as training those already acquired. This is important, because with good educators in the system, the schools will be better at fulfilling their educational goals.

Keywords: educator, upbringing, education, competencies, reflective practitioner, educator emancipator.

\footnotetext{
*Assoc. Prof. Aleksandra Golubović, Ph. D., Faculty of Humanities and Social Sciences, University of Rijeka, Sveučilišna avenija 4, 51000 Rijeka, Croatia, agolub@ffri.hr

** Petra Domaćinović, Faculty of Humanities and Social Sciences, University of Rijeka, Sveučilišna avenija 4, 51000 Rijeka, Croatia, domacinovicp@gmail.com
} 